\title{
Commercialization: Status and Way Forward
}

\author{
P. Srinivasa Rao, C. Ganesh Kumar and Belum V. S. Reddy
}

\begin{abstract}
Ethanol is a biofuel that is used as a fuel additive and a replacement for nearly $3 \%$ of the world's fossil fuel-based gasoline consumption. Currently, most of the bioethanol is produced from sugarcane in Brazil and corn in the United States, while biodiesel is made from rapeseed in Europe. The rationale for the success of the Brazilian Proalcool program, its present status and its perspectives has been presented. The Proalcool program's mandate was a vast increase in ethanol production with a sound government-backed subsidies and incentives initially to reach the goal; however, it was the private investors and companies that were solely responsible to achieve the end result. The Proalcool program indeed provides several essential lessons to many countries around the world about the potential competitiveness of biofuels vis-à-vis traditional fuels. Considering the importance of alternate biofuels, sweet sorghum has been identified as a promising energy crop to meet the energy security and reduce the dependence on fossil fuels in many countries around the globe. The Indian National Biofuel Policy (2009) recognizes sweet sorghum as a major biofuel feedstock and well adapted to India. However, its value chain could not get popular as anticipated due to low price level (Rs. 27) fixed by Government of India. Hence, it is necessary to review the ethanol price in India so as to give fillip to the beleaguered biofuel industry, which will likely to play a stabilization role in a oil import dependent economy like ours. Similarly, a number of case studies are presented on the research efforts made in various countries around the world like India, USA, Brazil and China on the use of sweet sorghum as
\end{abstract}

P. Srinivasa Rao $(\square) \cdot$ B. V. S. Reddy

International Crops Research Institute for the Semi-Arid Tropics (ICRISAT),

Patancheru 502324, India

e-mail: psrao72@gmail.com

C. Ganesh Kumar

Chemical Biology Laboratory, CSIR-Indian Institute of Chemical Technology (CSIR-IICT),

Uppal Road, Hyderabad 500607, India 
a potential bioenergy feedstock. The current and commercialization status of the various biofuel technologies and approaches are discussed. The biofuel blending targets and mandates of different countries are also presented.

Keywords Commercialization - Biofuel blending targets • Brazil • Sweet sorghum • Proalcool $\cdot$ Sugarcane $\cdot$ Manioc $\cdot$ Distilleries $\cdot$ Renewable $\cdot$ Bioethanol Genetic improvement $\cdot$ Sorganol $\cdot$ Feedstocks

\section{Overview}

Bioenergy has become a priority area for research and development worldwide and nations are investing heavily to increase their energy security and reduce their fossil-fuel carbon emissions and pollution. More than 50 countries, including several developing countries, have adopted blending targets or mandates and several more have announced biofuel quotas for future years (Table 1).

As a result now biofuels provide around $3 \%$ of total road transport fuel globally (on an energy basis) and considerably higher shares are achieved in certain countries and its share is expected to reach $27 \%$ of energy basket by 2050. Brazil, currently, met about $21 \%$ of its road transport fuel demand in 2008 with biofuels. Similarly, in the United States, the share was $4 \%$ of road transport fuel and in the European Union (EU) around $3 \%$ in 2008. For this, a wide variety of conventional and advanced biofuel conversion technologies exists today. The current status of the various technologies and approaches to biofuel production is given in Fig. 1. Conventional biofuel processes, though already commercially available, continue to improve in efficiency and economics. Advanced conversion/ processing technologies are moving to the demonstration stage or are already there (e.g., biomethane/syngas production).

\section{The Success Story: Brazil}

In Brazil, the sugarcane production industry has historically been concentrated in two main areas in the country, the Northeast, in the states of Algoas and Pernambuco and the Center South, in the state of Sao Paulo, where a large number of sugarcane plantations were owned and operated by small, independent farmers (Bolling and Suarez 2001). Later, the Brazilian government launched its biofuel initiative on 14 November 1975 by the presidential decree number 76.593, the PROALCOOL (Programa Nacional do Alcool) in response to the worldwide oil crisis in 1973 and to look possible domestic sources for alternative fuel production in order to insulate itself from the chaotic market (Cordonnier 2008). The program was aimed at bolstering Brazil's national sugar economy by safeguarding the 
Table 1 Overview of biofuel blending targets and mandates

\begin{tabular}{|c|c|c|c|}
\hline Country/region & $\begin{array}{l}\text { Current mandate/ } \\
\text { target }\end{array}$ & Future mandate/target & $\begin{array}{l}\text { Current status } \\
\text { (mandate }[\mathrm{M}] / \\
\text { target }[\mathrm{T}] \text { ) }\end{array}$ \\
\hline Argentina & E5, B7 & n.a. & M \\
\hline $\begin{array}{l}\text { Australia: New South } \\
\text { Wales (NSW), } \\
\text { Queensland (QL) }\end{array}$ & NSW: E4, B2 & $\begin{array}{l}\text { NSW: E6 (2011), B5 } \\
\text { (2012); QL: ES (on hold } \\
\text { till autumn 2011) }\end{array}$ & M \\
\hline Bolivia & E10, B2.5 & B20 (2015) & $\mathrm{T}$ \\
\hline Brazil & E20-25, B5 & n.a. & M \\
\hline Canada & $\begin{array}{l}\text { E5 (up to E8.5 in } 4 \\
\text { provinces), B2- } \\
\text { B3 (in } 3 \\
\text { provinces) }\end{array}$ & B2 (nationwide) (2012) & M \\
\hline Chile & E5, B5 & n.a. & $\mathrm{T}$ \\
\hline China (9 provinces) & E10 (9 provinces) & n.a. & M \\
\hline Colombia & E10, B10 & B20 (2012) & M \\
\hline Costa Rica & E7, B20 & n.a. & M \\
\hline Dominican Republic & n.a. & E15, B2 (2015) & n.a. \\
\hline European Union & $5.75 \%$ biofuels $^{\mathrm{a}}$ & $\begin{array}{l}10 \% \text { renewable energy in } \\
\text { transport }^{\mathrm{b}}\end{array}$ & $\mathrm{T}$ \\
\hline India & E5 & E20, B20 (2017) & M \\
\hline Indonesia & E3, B2.5 & $\begin{array}{l}\text { E5, B5 (2015); E15, B20 } \\
\text { (2025) }\end{array}$ & M \\
\hline Jamaica & E10 & $\begin{array}{l}\text { Renewable enegy in } \\
\text { transport: } 11 \%(2012) ; \\
12.5 \%(2015) ; 20 \% \\
(2030)\end{array}$ & M \\
\hline Japan & $\begin{array}{l}500 \mathrm{Ml} / \mathrm{y} \text { (oil } \\
\text { equivalent) }\end{array}$ & $800 \mathrm{Ml} / \mathrm{y}(2018)$ & $\mathrm{T}$ \\
\hline Kenya & E10 (in Kisumu) & n.a. & M \\
\hline Korea & B2 & B2.5 (2011); B3 (2012) & M \\
\hline Malaysia & B5 & n.a. & M \\
\hline Mexico & E2 (in Guadalajara) & $\begin{array}{l}\text { E2 (in Monterrey and } \\
\text { Mexico City; 2012) }\end{array}$ & M \\
\hline Mozambique & n.a. & E10, B5 (2015) & n.a. \\
\hline Norway & $3.5 \%$ biofuels & $\begin{array}{l}5 \% \text { proposed for } 2011 ; \\
\text { possible alignment with } \\
\text { EU mandate }\end{array}$ & M \\
\hline Nigeria & E10 & n.a. & $\mathrm{T}$ \\
\hline Paraguay & E24, B1 & n.a. & M \\
\hline Peru & $\mathrm{E} 7.8, \mathrm{~B} 2$ & B5 (2011) & M \\
\hline Philippines & E5, B2 & B5 (2011), E10 (Feb. 2012) & $\mathrm{M}$ \\
\hline South Africa & n.a. & $2 \%(2013)$ & n.a. \\
\hline Taiwan & B2, E3 & n.a. & M \\
\hline Thailand & B3 & $\begin{array}{c}3 \mathrm{Ml} / \mathrm{d} \text { ethanol, B5 (2011); } \\
9 \mathrm{Ml} / \mathrm{d} \text { ethanol (2017) }\end{array}$ & M \\
\hline Uruguay & B2 & E5 (2015), B5 (2012) & M \\
\hline
\end{tabular}


Table 1 (continued)

\begin{tabular}{|c|c|c|c|}
\hline Country/region & $\begin{array}{l}\text { Current mandate/ } \\
\text { target }\end{array}$ & Future mandate/target & $\begin{array}{l}\text { Current status } \\
\text { (mandate }[\mathrm{M}] \\
\text { target }[\mathrm{T}] \text { ) }\end{array}$ \\
\hline United States & $\begin{array}{l}48 \text { billion liters of } \\
\text { which } 0.02 \text { bln. } \\
\text { cellulosic- } \\
\text { ethanol }\end{array}$ & $\begin{array}{l}136 \text { billion liters, of which } \\
60 \text { bln. cellulosic- } \\
\text { ethanol (2022) }\end{array}$ & M \\
\hline Venezuela & E10 & n.a. & $\mathrm{T}$ \\
\hline Vietnam & n.a. & $\begin{array}{l}50 \mathrm{Ml} \text { biodiesel, } 500 \mathrm{Ml} \\
\text { ethanol }(2020)\end{array}$ & n.a. \\
\hline Zambia & n.a. & E5, B10 (2011) & n.a. \\
\hline
\end{tabular}

B: biodiesel (B2: $2 \%$ biodiesel blend); E: ethanol (E2: $2 \%$ ethanol blend); M1/d: million liters per day. n.a.: not available

${ }^{\text {a }}$ Currently, each member state has set up different targets and mandate

${ }^{\mathrm{b}}$ Lignocellulosic biofuels, as well as biofuels made from wastes and residues, count twice and renewable electricity 2.5 -times towards the target

Source International Energy Agency (2010) analysis based on various governmental sources. For more information see also: http://renewables.iea.org

\begin{tabular}{|c|c|c|c|c|}
\hline & & $\begin{array}{l}\text { Advanced } \\
\text { biofuels }\end{array}$ & & $\begin{array}{c}\text { Conventional } \\
\text { biofuels }\end{array}$ \\
\hline & Basic and applied R\&D & Demonstration & Early commercial & Commercial \\
\hline Bioethanol & & Cellulosic ethanol & & $\begin{array}{l}\text { Ethanol from sugar } \\
\text { and starch crops }\end{array}$ \\
\hline $\begin{array}{l}\text { Diesel-type } \\
\text { biofuels }\end{array}$ & $\begin{array}{l}\text { Biodiesel from microalgae; } \\
\text { Sugar-based hydrocarbons }\end{array}$ & $\begin{array}{l}\text { BtL-diesel (from } \\
\text { gasification + FT) }\end{array}$ & $\begin{array}{l}\text { Hydrotreated } \\
\text { vegetable oil }\end{array}$ & $\begin{array}{c}\text { Biodiesel (by } \\
\text { transesterification) }\end{array}$ \\
\hline $\begin{array}{l}\text { Other fuels } \\
\text { and additives }\end{array}$ & Novel fuels (e.g. furanics) & $\begin{array}{l}\text { Biobutanol, DME, } \\
\text { Pyrolysis-based fuels }\end{array}$ & Methanol & \\
\hline Biomethane & & ${\mathrm{Bio}-\mathrm{SG}^{4}}^{4}$ & & $\begin{array}{l}\text { Biogas (anaerobic } \\
\text { digestion) }\end{array}$ \\
\hline Hydrogen & $\begin{array}{cc}\text { All novel routes } & \begin{array}{c}\text { Gasification } \\
\text { with } \\
\text { reforming }\end{array}\end{array}$ & Biogas reforming & & \\
\hline
\end{tabular}

Liquid biofuel Gaseous biofuel

1. Biomass-to-liquids; 2. Fischer-Tropsch; 3. Dimethyl ether; 4. Bio-synthetic gas

Fig. 1 Commercialization status of main biofuel technologies (Source Modified from Bauen et al. 2009)

privately owned sugar industry and to substitute the petroleum oil imports with that of locally produced ethanol by converting surplus sugar into anhydrous ethanol. The program implemented and regulated the use of hydrated ethanol as fuel by blending it with petroleum gasoline. Article 2 of the Proalcool decree 


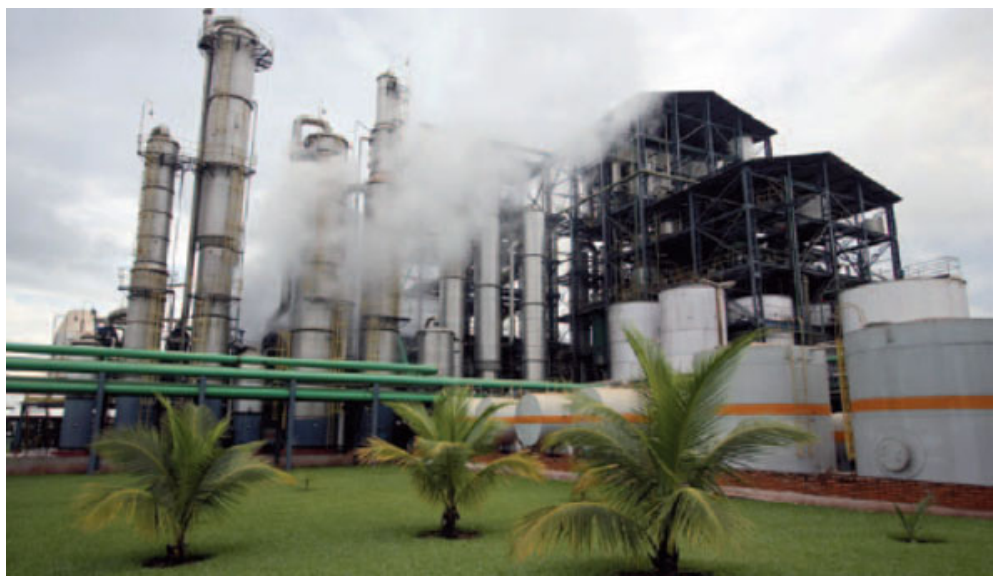

Fig. 2 Moema sugar mill located in Orindiuva, Sao Paulo, Brazil, producing transport-grade biofuel (Source Moraes 2011)

allowed the use of either sugarcane or manioc root for the production of ethanol and the specific mandate was to produce 3.5 billion liters of ethanol from sugarcane by 1980. Proalcool offered subsidies to both manioc-based plants and sugar cane-based plants (Fig. 2); the de facto standard in the alcohol industry was to establish plants producing 120,000 to 240,000 1/day, a scale that far exceeded the typically smaller manioc plants. The price paid to producers in 1980 was US $\$ 700$ for 1,000 l; over the years with the gains in the technology and economics of scale has driven the production costs down, reaching as low as US\$200 per 1,000 1 in 2004. In the past thirty five years, the ethanol industry has expanded enormously due largely to strong governmental incentives, subsidies, mandates and pro-ethanol legislation. Demetricus (1990) disputed that low agricultural productivity and production led most investors to choose sugarcane as the preferred raw material for ethanol production. The Proalcool program's mandate was a vast increase in ethanol production with a sound government-backed subsidies and incentives to reach that goal; however, it was the private investors and companies that were solely responsible to achieve the end result. In the course of time, the Brazilian ethanol market experienced a phase of rapid expansion stimulated by the development of flex fuel vehicles (FFVs). The ethanol content in these blends started initially at $5 \%$ and the current Brazil's government mandates has increased to up to $25 \%$ blending (currently even up to E85-E100 in FFVs) in gasoline since the last thirty five years of Proalcool. The history of ethanol production in Brazil provides an interesting insight into how an authoritarian regime, dedicated to promote an alternative renewable fuel, managed to achieve that goal. The Proalcool program indeed provides several essential lessons to many countries around the world about the potential competitiveness of biofuels vis-à-vis traditional fuels. Brazil with a vibrant biofuel industry has about 437 ethanol producing plants and a typical plant crushes about 2 million tons of sugarcane per year (Goldemberg 
2008) and annually turns half of its sugarcane harvest into 20 billion liters of ethanol to power 12.5 million vehicles ( $45 \%$ of Brazilian vehicles). Majority of the large plants are located in the state of Sao Paulo where almost two-thirds of the ethanol is being produced. Today Brazil is the highest producer of ethanol in world after USA and the government intervention is basically limited to determining the proportion of the anhydrous ethanol blend, setting the tax rate on sugar exports, etc.

\section{The Sweet Sorghum Story}

Research experiences gained on the cultivation of sweet sorghum in India, USA, Brazil and China have shown that the crop has high potential as a bio-energy feedstock, with several opportunities for immediate use as a complementary feedstock in dry and semi-arid land pockets and as a seasonal low-cost feedstock (mold-affected grain). Regions with a warm climate, large tracts of land and a system similar to sugarcane processing should work well for sweet sorghum. Further, the crop can be grown in regions of the world where sugarcane cannot be cultivated. The required government policy support is necessary for utilization of this novel feedstock for commercial bioethanol production. Across the globe a handful of distilleries started using sweet sorghum for ethanol production on commercial scale since 2007. M/s. Rusni Distilleries Pvt. Ltd. is the first sweet sorghum distillery established in 2007 at Sangareddy, Medak district of Andhra Pradesh, India and is amenable to multiple feedstocks. It has a production capacity of $40 \mathrm{kl} /$ day (KLPD) and produces fuel ethanol (99.6\% alcohol), Extra Neutral Alcohol (ENA, $96 \%$ ) and pharma alcohol (99.8 \%) from different agro-based raw materials such as sweet sorghum stalks (juice), molded grains, broken rice, cassava and rotten fruits. Another, 30 KLPD Tata Chemicals Limited distillery located in Nanded, Maharashtra, started operations in 2009 solely based on sweet sorghum and produced $90 \mathrm{KL}$ of transport grade ethanol in 2010. However, both the distilleries stopped operations primarily due to low market price of ethanol (Rs. 27 or 50 cents per litre).

The Chinese bioethanol production cost from corn is equivalent to 1.022 US\$/ liter, while the U.S. bioethanol production cost from corn was 0.492 US\$/liter (Licht 2008). The feedstock cost of sweet sorghum was 2,000 Yuan/ton, while the bioethanol production cost from sweet sorghum was 4,400 Yuan/ton (Song et al. 2008). In view of the high feedstock prices, the Chinese government is providing subsidies to cover the operating costs. The average subsidy for fuel bioethanol production set by the Chinese government was 1,836 Yuan/ton in 2005, 1,625 Yuan/ton in 2006, 1,374 Yuan/ton in 2007, and 1,754 Yuan/ton in 2008. Further, it was estimated that the removal of Value Added Tax and Consumption Tax which totaled to about 190 million Yuan (US\$28 million), and the direct financial subsidy totaled to about 2 billion Yuan (US\$294 million) for grain-based bioethanol plants from 2002 to 2008 (Lang et al. 2009). In January 2006, the Chinese government 
enacted the "Renewable Energy Law" to promote renewable energy utilization and production. Saline alkaline soils were preferred in a number of Chinese provinces for cultivating sweet sorghum; however, the production status was much lower as compared to corn production. In 2010-2011, the Chinese sweet sorghum production was 1.5 million tons and corn production was 28.6 million tons (USDA-FAS 2011). In addition, the Chinese sweet sorghum-bioethanol production was technically immature and bioethanol content was so low (20\%) that it could not be used as fuel (Wang 2011). At present, the status of biofuel production from sweet sorghum in China is still in the pilot scale project stage. Different biomass producing companies based in China such as Liaoning Guofu Bioenergy Development Company Limited, Binzhou Guanghua Biology Energy Company Ltd, Jiangxi Qishengyuan Agri-Biology Science and Technology Company Ltd, Xinjiang Santai Distillery, Jilin Fuel Alcohol Company Limited, Heilongjiang Huachuan Siyi Bio-fuel Ethanol Company Ltd, ZTE Agribusiness Company Limited and Fuxin Green BioEnergy Corporation-have conducted large-scale sweet sorghum trials. However, a few problems were identified in the processing of sweet sorghum stalks. In 2010, ZTE Agribusiness Company Limited, Wuyuan County, Inner Mongolia and Fuxin Green BioEnergy Corporation, Heishan County, Shenyang province used sweet sorghum as feedstock to produce ethanol. The Chinese government was encouraging sweet sorghum processing industries by offering a subsidy of $¥ 180 \mathrm{mu}^{-1}$ to farmers or companies cultivating sweet sorghum and $¥ 1300 \mathrm{t}^{-1}$ for ethanol produced to the industry. Given these sops, the area under sweet sorghum is likely to increase substantially in the near future.

In the Philippines, San Carlos Bio-Energy Incorporated set up the first commercial bioethanol distillery for fuel production at Visyan Islands of Negro. This firm used the sweet sorghum variety SPV 422 developed at ICRISATPatancheru and $14 \mathrm{~K}$ fuel grade ethanol was produced in 2012 from sweet sorghum syrup (247 1 of fuel grade ethanol from a ton of syrup). In addition, it used sugarcane to extend the operation of the distillery during the offseason. Further, several upcoming sugarcane distilleries in the provinces of Bukidnon (Mindanao), Tarlac and Pampanga (Luzon), which have large tracts of idle land suitable for sweet sorghum cultivation, are exploring the possibility of using sweet sorghum as a complementary feedstock. In Bicol region of Philippines, a development program on the commercialization of sweet sorghum products and by-products was implemented through public-private sector partnership. At Batac, Bapamin enterprises lead by Antonio Arcangel is marketing vinegar $(1,000 \mathrm{l} / \mathrm{month})$ and other food products from sweet sorghum commercially since 2008 (Reddy et al. 2011).

In USA, EnviroFuels, LLC, Riverview, Florida is currently in the process of developing a 30 million gallon per year sugar-based Advanced Biofuel ethanol plant in Highlands County, Florida using sweet sorghum as the primary feedstock. Sugarcane will be used to supplement the feedstock base in the winter months when sweet sorghum is not available. Another firm, Southeast Renewable Fuels LLC is building a 20 million gallon per year sweet sorghum-to-ethanol advanced bio-refinery in Hendry County, near Clewiston, Florida. BioDimensions Industrial Sugar Platform Development, located in the state of Tennessee, USA, planted and 
harvested about 75 ha of sweet sorghum. A portion of the sugars was fermented to ethanol, while the bagasse was used for making both fuel pellets and animal feed. Energy sugar beets are the complementary off-season feedstock being used when sweet sorghum is not available. The group expects to distill about 5,000 gallons of hydrous ethanol, much of which will be used in an industrial ethanol engine.

The Ceres, Inc. established a subsidiary in Brazil is focusing on developing sweet sorghum as a feedstock for the ethanol industry. The company's goal is to be the first supplier of new hybrids with high levels of sugar. The company is currently working with multiple ethanol mills, technology providers and equipment companies to facilitate the introduction of sweet sorghum hybrids into existing ethanol mills. The EMBRAPA is also closely working with several sugar mills and produced over 5,000 1 of transport grade ethanol on pilot scale basis in Sao Paulo region and has already indented 200 tonnes of seed for its sweet sorghum variety, BRS 506. It is anticipated that in the coming years, sweet sorghum will become the second most important bioethanol feedstock in Brazil after sugarcane, optimally exploiting the season between two sugarcane crops.

Net energy ratio and greenhouse gas balance primarily decides the benefits of an energy value chain. However, it was reported that sweet sorghum has a high net energy balance of 3.63 as compared to grain sorghum (1.50) and corn (1.53) balance (Wortmann et al. 2008). Another report estimated an energy balance of 8 and carbon emission reduction by $86 \%$ (CII-DBT Report 2010). First and second generation bioethanol from sweet sorghum can contribute significantly to the conservation of fossil resources and to the mitigation of greenhouse gases. If the crop is used for the production of ethanol (from grains and sugar) and green electricity (from surplus bagasse), 3,500 1 of crude oil equivalents can be saved per hectare cultivation area. If both food from grains and ethanol from the juice are produced, 2,300 1 of crude oil equivalents can be saved per hectare cultivated area. Regarding greenhouse gases, between 1.4 and $22 \mathrm{~kg} \mathrm{CO}_{2}$ equivalents can be saved depending on yield, production methods and the land cover prior to sweet sorghum cultivation (Köppen et al. 2009). For both categories, the exact values vary greatly with specific scenarios and local conditions. In general, the following parameters that determine the results are the type and efficiency of conversion technology, the use of byproducts (e.g., bagasse), the crop yield per cultivation area, land-use changes, as well as the type of fossil energy carriers that are replaced. Even if the seeds were used as food, bioethanol from the stem's sugar juice still shows clear advantages over fossil fuels. If both sugar and seeds were used as food, the respective conversion related energy and greenhouse gas expenditures could be compensated by producing second generation ethanol from the bagasse. Even though the ethanol yield per unit weight of feedstock is lower for sweet sorghum as compared to sugarcane, the much lower production costs and water requirement for this crop more than compensates for the difference, and hence, it still returns a competitive cost advantage for the production of ethanol in India (Farrell et al. 2006).

There are many factors affecting the sweet sorghum value chain. The following major challenges identified are: 
- $\mathrm{G} \times \mathrm{E}$ interactions were significant for sweet sorghum related traits; the genotypes that performed well in the rainy season were not necessarily the topperformers in the post-rainy season and vice versa. Preliminary results indicated that non-allelic interactions were more predominant for stalk sugar and allied traits.

- As global climate is gradually changing to higher temperatures and sweet sorghum is bound to grow in new areas, thermo- and photo-insensitive non-lodging cultivars that are resistant to multiple pests and diseases needs to be developed.

- Sugars accumulation and sustenance is a complex process and is governed by many alleles. Cool season or temperate sweet sorghums need to be evolved.

- Breeding of short, mid-late and late maturing genotypes is necessary in order to have a broad harvest window in sweet sorghum, and thus providing raw material to the distillery over a long period. Proper planning of sowing of a mixture of these cultivars in the catchment area of distillery would help in achieving more commercial stalk sugar/ethanol.

- When cultivars with different maturity groups are grown in an area, pests like shootfly and midge are prone to infest the late maturing cultivars. Therefore, breed for those insect-tolerant cultivars.

- Sorghum crop is traditionally challenged by marginal lands with poor fertility status and poor moisture holding capacity and sweet sorghum too encounters similar problems. Sporadic water inundation due to excessive rains/floods also becomes an unforeseen constraint.

- The self fermentation of juice inside the stalk prior to juice extraction is a major concern, mainly when juice extraction is delayed after harvesting due to long distances prevailing between factory and the field. Preliminary results indicated that there will be reduction in sugar yield by $16.8 \%$, if the juice extraction is delayed by $48 \mathrm{~h}$ (Srinivasarao et al. 2012). Research should therefore address the problem of post-harvest losses in terms of juice quality and quantity.

\section{Way Forward}

Sweet sorghum has a low water demand and is especially advantageous in areas with water shortage (Srinivasarao et al. 2011). Its lower nitrogen fertilizer demand possibly due to traits such as biological nitrification inhibition (BNI), reduces the risk of nutrient leaching and thus soil and water pollution, as well as making it well suited for small-scale farming. Its relatively short vegetation cycle allows sweet sorghum to be grown in double cropping systems which involves the harvesting of the crop twice or more number of times from a single planting during the growing season (Duncan and Gardner 1984) based on water availability, which in turn can lead to greater agro-biodiversity and a reduced demand for fertilizers and pesticides.

A limiting factor for its widespread cultivation is the limited availability of varieties/hybrids adapted to different agro-climatic conditions (e.g., lack of postrainy season adapted lines in India) resisting both biotic and abiotic stresses, 
including colder climate. Consequently, research should address the optimization of sweet sorghum as an energy crop through breeding for enhanced productivity under limited available resources. Genetic improvement should focus on stalk sugar, biomass quantity and quality and in general, agronomic traits (such as water and nutrient use efficiency) and in particular, adaptation of sweet sorghum to colder, arid saline, and alkaline conditions. Further, an improvement in Brix\%, juice volume and stalk yield ( $\geq 45 \mathrm{t} \mathrm{ha}^{-1}$ with hybrids) should be targeted in sweet sorghum to help improve the benefits to the industry and farmers without any detrimental effect on grain yield. The juice volume should not be compromised, while increasing the Brix \%. There is also a need to develop and evaluate cultivars producing high stalk yield per unit time, input, energy and land area in different agro-climatic regions of the country. Other research areas on quality and processing which needs immediate attention include high ethanol yield, fermentation efficiency, diffusion, diversified products from bagasse (power, pulp, bio-manure, cattle feed, etc.).

As the demand for biofuels rapidly expands, its associated production systems and supply chains are consolidating. Forward-thinking management systems could significantly enhance ecological sustainability and livelihood development, particularly for poor farmers in the developing world. International trade will be crucial to enlarge the share of bioethanol in future transport energy demand. In the longer terms, developing countries can profit from the experiences with sustainable conventional biofuel production (e.g., Brazil and USA) and later adopt advanced biofuel technologies once they are commercially proven. If the countries with sound policy framework targeting the entire sweet sorghum innovation chain to ensure that the development and use of biofuels, in general and sorganol in particular, would reap rich dividends in climate change mitigation and adaptation, energy security and all round sustainable economic development, without compromising food or feed security. Full exploration of the available genetic resources through plant breeding with the aid of molecular tools could dramatically increase biomass yield of sorghum and thus meet the demand of feedstocks for biofuel production without a significant impact on our food supply and natural environment.

Acknowledgments We would like to thank the donor agencies-International Fund for Agriculture Development (IFAD), National Agriculture Innovation Project (NAIP-ICAR), and European Commission-SWEETFUEL (EC) for funding projects on sweet sorghum improvement and value chain development to further the cause of SAT farmers. The efforts of Mr. K Devendram, Mr. B. Ramaiah, Mr. Ch. Madhu (ICRISAT); Dr. R. Nageswar Rao, Dr. M. Vairamani and Mrs. Sara Khalid (IICT) in field and lab data collection and analysis are also acknowledged.

\section{References}

Bauen A, Berndes G, Junginger M, Londo M, Vuille F (2009) Bioenergy—a sustainable and reliable energy source. A review of status and prospects. IEA Bioenergy: ExCo:2009:06

Bolling C, Suarez NR (2001) The Brazilian sugar industry: recent developments, sugar and sweetener situation \& outlook/SSS-232 (Sept. 2001) (Economic Research Service/USDA). http.//www.ers.usda.gov/BriefingBrazil/braziiansugar.pdf 
CII-DBT Report (2010) Estimation of energy and carbon balance of biofuels in India, Feb 2010

Cordonnier VM (2008) Ethanol's roots: how Brazilian legislation created the international ethanol boom. William Mary Environ Law Policy Rev 33:287-317

Demetricus FJ (1990) Brazil's national alcohol program: technology and development in an authoritarian regime. Praeger Publishers, New York, $181 \mathrm{pp}$

Duncan RR, Gardner WA (1984) The influence of ratoon cropping on sweet sorghum yield, sugar production, and insect damage. Can J Plant Sci 64:261-273

Farrell AE, Plevin RJ, Turner BT, Jones AD, O'Hare M, Kammen DM (2006) Ethanol can contribute to energy and environmental goals. Science 311(5760):506-508

Goldemberg J (2008) The Brazilian biofuels industry. Biotechnol Biofuels 1:6. doi:10.1186/ 1754-6834-1-6

International Energy Agency (2010) Sustainable production of second generation bio-fuels: potential and perspectives in major economies and developing countries

Köppen S, Reinhardt G, Gärtner S (2009) Assessment of energy and greenhouse gas inventories of sweet sorghum for first and second generation bioethanol. FAO Environmental and Natural Resources Service Series, No. 30, FAO, Rome, 83 pp

Lang X, Zheng F, Cui H (2009) Evolution of fuel ethanol policy in China. For Econ, pp 29-33

Licht FO (2008) Ethanol production costs a worldwide survey, F.O. Licht, Ratzeburg, Germany. ISSN 14785765

Moraes M (2011) Lessons from Brazil. Nature 474:S25-S25

Reddy BVS, Layaoen H, Dar WD, Srinivasa Rao P, Eusebio JE (Eds.) (2011) Sweet sorghum in the Philippines: status and future. International Crops Research Institute for the Semi-Arid Tropics, Patancheru 502 324, Andhra Pradesh, India. 116 pp

Song A, Pei G, Wang F, Wan D, Feng C (2008) Survey for fuel biofuel feedstock multiple production. Acad Report Agric Process 24:302-307

Srinivasarao P, Sanjana Reddy P, Rathore A, Reddy BVS, Sanjeev P (2011) Application of GGE biplot and AMMI model to evaluate sweet sorghum (Sorghum bicolor) hybrids for genotype $\times$ environment interaction and seasonal adaptation. Indian J Agric Sci 81:438-444

Srinivasarao P, Kumar CG, Malapaka J, Kamal A, Reddy BVS (2012) Feasibility of sustaining sugars in sweet sorghum stalks during post-harvest stage by exploring cultivars and chemicals: a desk study. Sugar Tech 14:21-25

USDA-FAS (U.S. Department of Agriculture, Foreign Agricultural Service) (2011) PS\&D, USDA-FAS, 01.03.2011. http://www.fas.usda.gov/psdonline/psdQuery.aspx

Wang QA (2011) Time for commercializing non-food biofuels in China. Renew Sustain Energy Rev 15:621-629

Wortmann C, Ferguson R, Lyon D (2008) Sweet sorghum as a biofuel crop in Nebraska. Paper presented at the 2008 Joint Annual Meeting, Celebrating the International Year of Planet Earth, 5-9 Oct 2008, Houston, Texas. http://crops.confex.com/crops/2008am/techprogram/ P44581.htm 